\title{
APPLICATION OF THE FIRE RESISTING SUSPENDED CEILINGS
}

\section{ZASTOSOWANIE SUFITÓW PODWIESZONYCH O OKREŚLONE ODPORNOŚCI OGNIOWEJ}

DOI: 10.30540/sae-2018-021

\begin{abstract}
This paper presents the rules of performing fire resistance tests and classification of suspended ceilings constituting independent barriers and suspended ceilings constituting horizontal membranes protecting the floor/roof over them. The consequences for the way of using suspended ceilings in buildings, taking into account the requirements of the regulations, were discussed.
\end{abstract}

Keywords: suspended ceiling, fire resistance, floor, testing

\section{Streszczenie}

$W$ artykule przedstawiono zasady wykonywania badań oraz klasyfikowania w zakresie odporności ogniowej sufitów podwieszonych stanowiacych samodzielne przegrody oraz sufitów podwieszonych stanowiacych poziome membrany zabezpieczające strop/dach nad nimi. Omówiono konsekwencje dla sposobu zastosowania sufitów podwieszonych w budynkach z uwzględnieniem wymagań przepisów.

Słowa kluczowe: sufit podwieszony, odporność ogniowa, strop, badania

\section{INTRODUCTION}

In today's buildings, the demands on the interior finish of the building are increasing. These requirements apply both to the aesthetic side and, above all, to the functional aspects. Suspended ceilings may have several functions at the same time. They can be used e.g. to cover installation elements (in particular ventilation and air-conditioning installation), to improve acoustic parameters of the room, to install loudspeakers and lighting installation elements directly in the ceiling, but also to increase fire resistance of the floor/roof (floor/roof system + suspended ceiling). Therefore, suspended ceilings are often installed in general construction facilities, e.g. in hospitals, schools, kindergartens, hotels, offices, banks, sports and entertainment halls, shopping malls, shopping halls, production halls, social

\section{WPROWADZENIE}

We wznoszonych obecnie budynkach coraz wyższe wymagania stawiane są wykończeniu wnętrza budynku. Wymagania te dotyczą zarówno strony estetycznej, jak i przede wszystkim kwestii użytkowych. Sufity podwieszone mogą pełnić jednocześnie kilka funkcji. Mogą być wykorzystywane np. do zasłonięcia elementów instalacji (w szczególności instalacji wentylacyjnej i klimatyzacyjnej), poprawienia parametrów akustycznych pomieszczenia, montażu bezpośrednio w suficie głośników i elementów instalacji oświetleniowej, ale także do zwiększenia odporności ogniowej stropu/dachu (układu strop/dach + sufit podwieszony). Dlatego też sufity podwieszone są chętnie montowane w obiektach budownictwa ogólnego, np.: w szpitalach, szkołach, przedszkolach, hotelach, biurach, bankach, salach sportowych i widowiskowych, centrach han- 
welfare homes, health centres, boarding houses and guesthouses. Depending on the needs and accepted design solutions, different construction and material solutions are used. A structural element is usually a steel grid, to which various panels are fixed or supported, e.g. gypsum plasterboards, gypsum-fibre boards, cement boards, cement-particle boards, or mineral wool (also pressed) boards, but also various panels.

If fire resistance of the suspended ceiling is not required in a given area or if it is not required that the suspended ceiling contributes to the fire resistance of the floor-ceiling system (roof-ceiling), then suspended ceilings with a purely decorative/finishing function may be used to cover structural elements and/or installations laid in the space between the suspended ceiling and the floor, i.e. either as finished surface themselves or to provide a final finish (e.g. paints, wallpaper, etc.).

\section{THE FUNCTIONS OF SUSPENDED CEILINGS}

Due to fire safety requirements, suspended ceilings may have the following functions:

a) increase the fire resistance of the floor,

b) protect users (for a limited period of time) from fire in the space between the suspended ceiling and the floor,

c) protect the installations laid in the space between the suspended ceiling and the floor from fire in the room.

In order to improve the fire resistance class of the floor, suspended ceilings are used as independent barriers, classified according to the criteria of fire integrity and fire insulation under fire exposure from the below - from the room side. This scenario is illustrated in Figure 1. The floor construction shown in Figure 1 should meet the load-bearing capacity requirements at normal temperature. A suspended ceiling, which constitutes an independent barrier of a specified fire resistance, ensures fire integrity and fire insulation of the entire system for the required time. The temperature increase in the space between the suspended ceiling and the floor/roof, and consequently in the steel beams of the floor, is small and does not lead to a significant change in the properties of the steel nor, as a result, to the loss of the load-bearing capacity of the structure. Also for other floor/roof structures - composite, concrete or timber - the temperature increase in the space between the suspended ceiling and the floor/roof will not lead to significant changes in the properties of the structural dlowych, pawilonach handlowych, halach produkcyjnych, domach opieki społecznej, ośrodkach zdrowia, internatach i pensjonatach. W zależności od potrzeb i przyjętych rozwiązań projektowych stosowane są różne rozwiązania konstrukcyjne i materiałowe. Elementem konstrukcyjnym jest na ogół ruszt stalowy, do którego mocuje się lub opiera się na nim różne płyty, np.: gipsowo-kartonowe, gipsowo-włóknowe, cementowe, cementowo-wiórowe czy z wełny mineralnej (także prasowanej), ale także różne panele.

Jeśli w danym obszarze $\mathrm{w}$ stosunku do sufitów podwieszonych nie stawia się wymagań w zakresie odporności ogniowej lub nie jest wymagany udział sufitu podwieszonego w odporności ogniowej układu strop-sufit (dach-sufit), mogą być stosowane sufity podwieszone pełniące wyłącznie funkcję dekoracyjną/ wykończeniową w celu zasłonięcia elementów konstrukcyjnych i/lub instalacji prowadzonych w przestrzeni pomiędzy sufitem podwieszonym a stropem, i albo same stanowią wykończenie powierzchni, albo umożliwiają wykonanie docelowego wykończenia (np. farbami, tapetą itp.).

\section{FUNKCJE SUFITÓW PODWIESZONYCH}

$\mathrm{Z}$ uwagi na wymagania w zakresie bezpieczeństwa pożarowego, sufity podwieszone mogą pełnić następujące funkcje:

a) podwyższać odporność ogniową stropu,

b) chronić użytkowników (przez określony czas) przed pożarem $\mathrm{w}$ przestrzeni pomiędzy sufitem podwieszonym a stropem,

c) ochraniać przed pożarem w pomieszczeniu instalacje prowadzone w przestrzeni pomiędzy sufitem podwieszonym a stropem.

W celu podwyższenia klasy odporności ogniowej stropu stosowane są sufity podwieszone, stanowiące samodzielne przegrody sklasyfikowane $\mathrm{z}$ uwagi na kryteria szczelności ogniowej i izolacyjności ogniowej przy oddziaływaniu ognia od dołu - od strony pomieszczenia. Scenariusz ten zilustrowano na rysunku 1. Przedstawiona na rysunku 1 konstrukcja stropu spełnia wymagania nośności w temperaturze normalnej. Sufit podwieszony stanowiący samodzielną przegrodę o określonej odporności ogniowej, samodzielnie zapewnia szczelność ogniową i izolacyjność ogniową całego układu przez wymagany czas. Przyrost temperatury w przestrzeni pomiędzy sufitem podwieszonym a stropem/dachem, a w konsekwencji w belkach stalowych stropu, jest niewielki i nie prowadzi do istotnej zmiany właściwości stali, ani w konsekwencji do utraty nośności konstrukcji. Także w przypadku innych konstrukcji 
materials and, consequently, to a loss of load-bearing capacity of the structure. This scheme is valid for all properly designed floors (as well as roofs) of any construction, unless it is sensitive to a temperature increase of $200^{\circ} \mathrm{C}$.
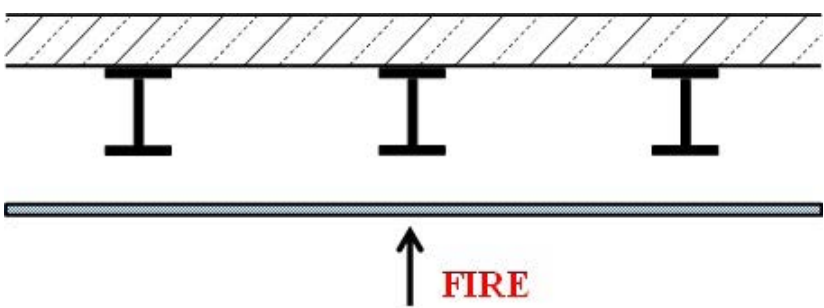

In order to protect users from fire in the space between the suspended ceiling and the floor/roof, suspended ceilings are used as independent barriers, classified according to the fire integrity and fire insulation criteria, under fire exposure from the top - from the space between the suspended ceiling and the floor/roof. This scenario is illustrated in Figure 2. The floor construction shown in Figure 2 should meet the requirements for loadbearing capacity, fire integrity and fire insulation (in the case of a roof - loadbearing capacity and fire integrity) under fire exposure from below for the required time. A suspended ceiling constituting independent barrier of specified fire resistance in the case of fire exposure from above, independently ensures fire integrity and fire insulation in the case of such fire exposure for the required period of time.

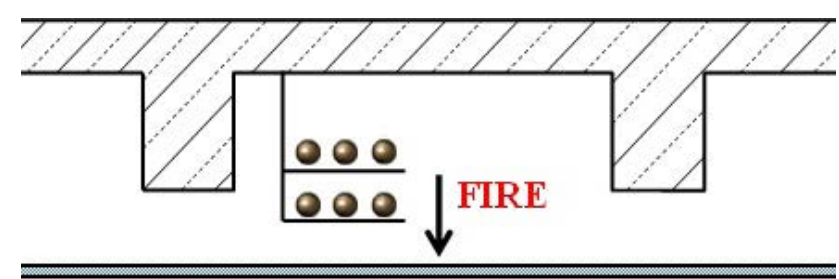

If there is a need to provide protection of the installations laid in the space between the suspended ceiling and the floor/roof against fire in the room, the suspended ceilings constituting independent barriers classified according to the criteria of fire integrity and fire insulation under fire exposure from below from the room are used. This scenario is illustrated in Figure 3. The floor structure shown in Figure 3 stropu/dachu - zespolonych, betonowych czy drewnianych - przyrost temperatury w przestrzeni pomiędzy sufitem podwieszonym a stropem/dachem nie będzie prowadził do istotnych zmian właściwości materiałów konstrukcyjnych, a w konsekwencji do utraty nośności konstrukcji. Schemat ten obowiązuje dla wszystkich prawidłowo zaprojektowanych stropów (a także dachów) o dowolnej konstrukcji, o ile nie będzie ona wrażliwa na przyrost temperatury rzędu $200^{\circ} \mathrm{C}$.

Fig. 1. Suspended ceiling used to increase the fire resistance of the floor

Rys. 1. Sufit podwieszony stosowany w celu podwyższenia odporności ogniowej stropu [źródto: rysunek własny]

W celu zapewnienia ochrony użytkowników przed pożarem instalacji $\mathrm{w}$ przestrzeni pomiędzy sufitem podwieszonym a stropem/dachem stosowane są sufity podwieszone stanowiące samodzielne przegrody sklasyfikowane z uwagi na kryteria szczelności ogniowej i izolacyjności ogniowej przy oddziaływaniu ognia od góry - od strony przestrzeni pomiędzy sufitem podwieszonym a stropem/dachem. Scenariusz ten zilustrowano na rysunku 2. Przedstawiona na rysunku 2 konstrukcja stropu powinna spełniać wymagania nośności ogniowej, szczelności ogniowej i izolacyjności ogniowej (w przypadku dachu - nośności ogniowej i szczelności ogniowej) przy oddziaływaniu ognia od dołu przez wymagany czas. Sufit podwieszony, stanowiący samodzielną przegrodę o określonej odporności ogniowej przy oddziaływaniu ognia od góry, samodzielnie zapewnia szczelność ogniową i izolacyjność ogniową przy takim oddziaływaniu ognia przez wymagany czas.

Fig. 2. Suspended ceiling used to protect users from fire of installations laid between the suspended ceiling and the floor/roof

Rys. 2. Sufit podwieszony stosowany $w$ celu ochrony użytkowników przed pożarem instalacji prowadzonych $w$ przestrzeni pomiędzy sufitem podwieszonym a stropem/ dachem [źródto: rysunek własny]

W przypadku potrzeby zapewnienia ochrony instalacji prowadzonych w przestrzeni pomiędzy sufitem podwieszonym a stropem/dachem przed pożarem w pomieszczeniu stosowane są sufity podwieszone stanowiące samodzielne przegrody sklasyfikowane z uwagi na kryteria szczelności ogniowej i izolacyjności ogniowej przy oddziaływaniu ognia od dołu - od strony pomieszczenia. Scenariusz ten zilustrowano 
should meet the loadbearing capacity requirements for a specified period of time (generally unrelated to the installation fire protection time). The suspended ceiling constituting independent barrier of specified fire resistance, independently ensures fire integrity and fire insulation of the entire system. The increase of temperature in the space between the suspended ceiling and the floor/roof shall not lead to damage or destruction of the installations laid in that space for the required period of time.

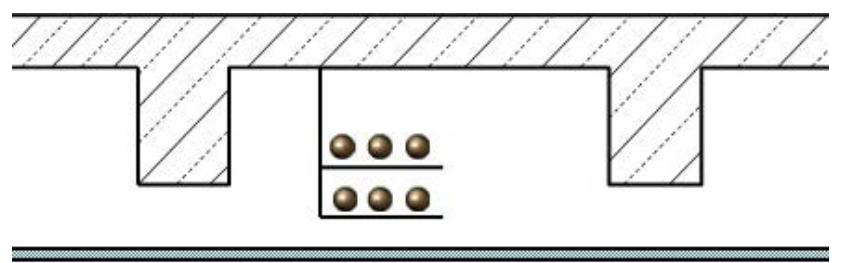

FIRE

\section{FIRE RESISTANCE TESTS AND CLASSIFICATION OF SUSPENDED CEILINGS}

\subsection{Suspended ceilings fire resistance tests}

The first fire resistance tests of suspended ceilings in ITB at the Fire Research Depatment took place in 1975-77 commissioned by the Central Research and Development Centre for General Construction, Warsaw, Wierzbowa street. A series of fire resistance tests of suspended ceilings made of gypsum plasterboards in a woodfired polygon chamber were carried out at that time. At present, in Fire Research Department of ITB in Pionki fire resistance tests are carried out in modern gas-fired furnaces, and the dimensions of the test elements may range from $3.3 \times 4.3 \mathrm{~m}$ to $11.2 \times 4.3 \mathrm{~m}$.

Since 1998, in Poland, fire resistance tests of suspended ceilings have been carried out in accordance with the PN-B-02875 [1] standard, which included both testing of the suspended ceiling as a independent barrier, as well as testing of the floor with the suspended ceiling constituting a horizontal protective membrane. The European standard PN-EN 1364-2 [2] (as well as the new just published version [3]) covers only fire resistance tests of suspended ceilings being independent barriers. The standard PNEN 13381-1 [4] concerning fire resistance testing of floor with suspended ceilings constituting horizontal protective membranes was published in 2014. na rysunku 3. Przedstawiona na rysunku 3 konstrukcja stropu powinna spełniać wymagania nośności ogniowej, przez określony czas (na ogół niezwiązany z czasem ochrony instalacji). Sufit podwieszony, stanowiący samodzielną przegrodę o określonej odporności ogniowej, samodzielnie zapewnia szczelność ogniową i izolacyjność ogniową całego układu. Przyrost temperatury w przestrzeni pomiędzy sufitem podwieszonym a stropem/dachem nie prowadzi do uszkodzenia bądź zniszczenia instalacji prowadzonych w tej przestrzeni przez wymagany czas.

Fig. 3. Suspended ceiling used to protect installations in the space between a suspended ceiling and the floor/roof from fire in the room

Rys. 3. Sufit podwieszony stosowany w celu ochrony instalacji prowadzonych w przestrzeni pomiędzy sufitem podwieszonym a stropem/dachem przed pożarem w pomieszczeniu [źródto: rys. własny]

\section{BADANIA ODPORNOŚCI OGNIOWE I KLASYFIKACJA SUFITÓW PODWIESZONYCH}

\subsection{Badania odporności ogniowej sufitów podwieszonych}

Pierwsze badania odporności ogniowej sufitów podwieszonych w ITB w Zakładzie Badań Ogniowych odbyły się w latach 1975-77 na zlecenie Centralnego Ośrodka Badawczo-Rozwojowego Budownictwa Ogólnego, Warszawa, ul. Wierzbowa. Przeprowadzono wówczas serię badań odporności ogniowej sufitów podwieszonych z płyt gipsowo-kartonowych $\mathrm{w}$ poligonowej komorze opalanej drewnem. Obecnie w ITB w Zakładzie Badań Ogniowych w Pionkach przeprowadza się badania odporności ogniowej w nowoczesnych piecach opalanych gazem, a wymiary elementów badanych mogą mieć od 3,3 x 4,3 m do 11,2 x 4,3 m.

Od 1998 roku w Polsce badania odporności ogniowej sufitów podwieszonych wykonywane były według normy PN-B-02875 [1], która obejmowała zarówno badanie sufitu podwieszonego jako samodzielnej przegrody, jak również badanie stropu z sufitem podwieszonym stanowiącym poziomą membranę zabezpieczającą. Norma europejska PN-EN 1364-2 [2] (a także właśnie opublikowana jej nowa wersja [3]) obejmuje tylko badania odporności ogniowej sufitów podwieszonych stanowiących samodzielne przegrody. Normę PN-EN 13381-1 [4] dotyczącą badania odporności ogniowej stropu z sufitem podwieszonym, stanowiącym poziomą membranę zabezpieczającą, opublikowano w 2014 roku. 


\subsection{Fire resistance tests of suspended ceilings constituting independent barriers}

Fire resistance tests of suspended ceilings, which are independent barriers, are performed according to the standard PN-EN 1364-2 [2]. This standard describes how the test is to be carried out both when exposed to fire from below and when exposed to fire from above. In both cases, the same thermal exposure defined by the standard time/temperature curve specified in PN-EN 1363-1 [5], defined by the formula (1), is applied:

$$
\mathrm{T}=345 \cdot \log _{10}(8 \cdot \mathrm{t}+1)+20
$$

where: $\mathrm{T}$ is the average temperature in the furnace, in degrees Celsius, $\mathrm{t}$ is time, in minutes.

The time/temperature curve is illustrated in Figure 4.

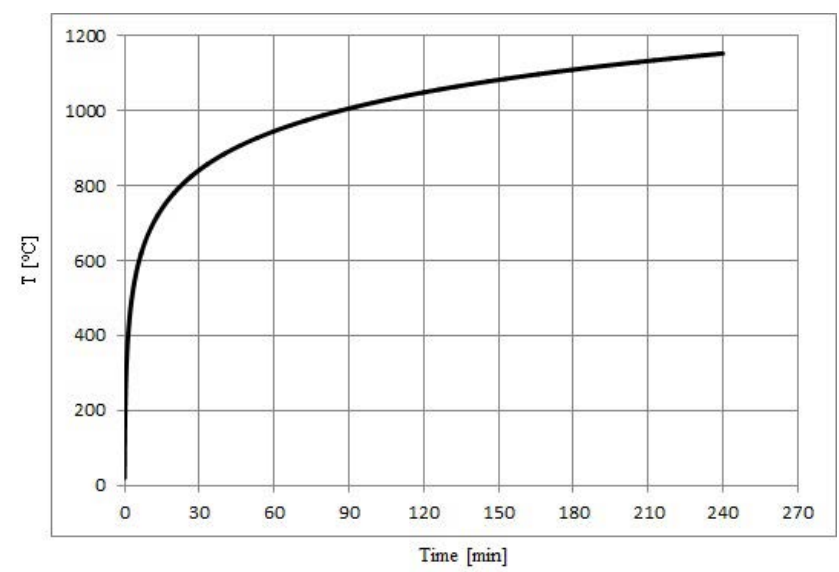

In the case of fire from below, the pressure in the furnace measured at a distance of $100 \mathrm{~mm}$ below the bottom surface of the suspended ceiling should not exceed $20 \mathrm{~Pa}$, with tolerances given in PN-EN 1363-1 [5].

In the case of fire from above, the difference between the pressure in the furnace measured at a distance of $100 \mathrm{~mm}$ above the surface of the suspended ceiling and the pressure in the furnace in the empty space under the suspended ceiling should not exceed $10 \mathrm{~Pa}$, in accordance with PN-EN 1364-2 [2].

The view of the suspended ceiling with gypsum plasterboard lining from the unexposed side during the fire resistance test is shown in Photo 1.

\subsection{Badania odporności ogniowej sufitów podwieszonych stanowiących samodzielne przegrody}

Badania odporności ogniowej sufitów podwieszonych stanowiących samodzielne przegrody są wykonywane według normy PN-EN 1364-2 [2]. W normie opisano sposób przeprowadzenia badania zarówno przy oddziaływaniu ognia od dołu, jak i przy oddziaływaniu ognia od góry. W obu przypadkach stosowane jest to samo oddziaływanie termiczne zdefiniowane standardową krzywą czas/temperatura podaną w PN-EN 1363-1 [5], określoną wzorem (1):

$$
\mathrm{T}=345 \cdot \log _{10}(8 \cdot \mathrm{t}+1)+20
$$

gdzie: $\mathrm{T}$ jest średnią temperaturą $\mathrm{w}$ piecu, $\mathrm{w}$ stopniach Celsjusza, t jest czasem, w minutach.

Krzywą czas/temperatura zilustrowano na rysunku 4.

Fig. 4. Standard time/temperature curve

Rys. 4. Standardowa krzywa czas/temperatura (źródto: $P N$ EN 1363-1:2012)

Ciśnienie w piecu przy oddziaływaniu ognia od dołu, mierzone w odległości $100 \mathrm{~mm}$ poniżej spodniej powierzchni sufitu podwieszonego, nie powinno przekraczać $20 \mathrm{~Pa}$, z tolerancjami podanymi w normie PN-EN 1363-1 [5].

Przy oddziaływaniu ognia od góry różnica pomiędzy ciśnieniem w piecu, mierzonym w odległości $100 \mathrm{~mm}$ powyżej powierzchni sufitu podwieszonego, a ciśnieniem w piecu w pustej przestrzeni pod sufitem podwieszonym nie powinna przekraczać $10 \mathrm{~Pa}$, zgodnie z normą PN-EN 1364-2 [2].

$\mathrm{Na}$ fotografii 1 przedstawiono widok sufitu podwieszonego z okładzinami z płyt gipsowo-kartonowych podczas badania odporności ogniowej od strony nienagrzewanej. 


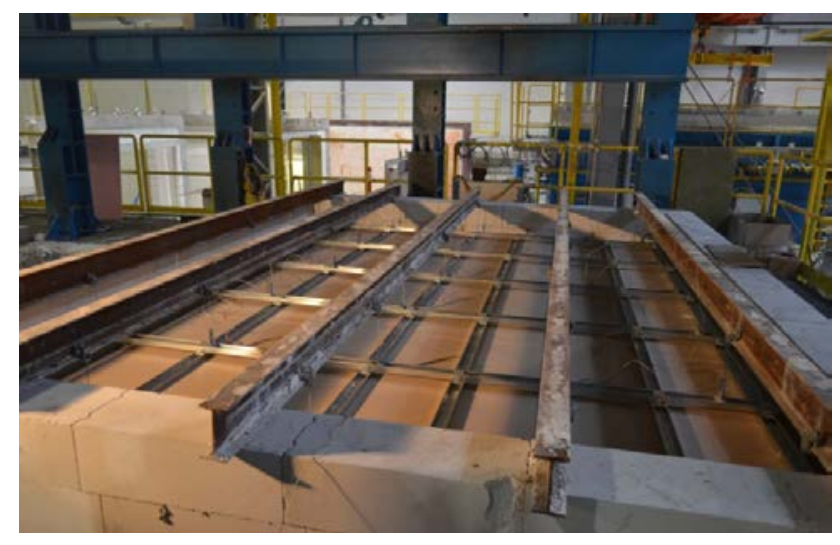

In the classification standard PN-EN 13501-2 [6] the fire resistance classification criteria are given for all building elements listed in the standard, including suspended ceilings constituting independent barriers.

The criteria for assessing the fire resistance of a suspended ceiling constituting independent barriers are as follows:

Fire integrity (E):

The assessment of fire integrity shall be made on the basis of the following three aspects:

a) gaps or openings in excess of the specified dimensions;

b) ignition of a cotton pad;

c) sustained flaming on the unexposed side.

Fire insulation (I):

The assessment of fire insulation shall be made on the basis of the following two aspects:

a) the mean temperature rise on the unexposed face is exceeded by $140 \mathrm{~K}$ above the initial average temperature;

b) the maximum temperature rise on the unexposed face is exceeded by $180 \mathrm{~K}$ above the initial average temperature.

The view of the suspended ceiling with gypsum plasterboard lining from the exposed side after the fire resistance test is shown in Photo 2.

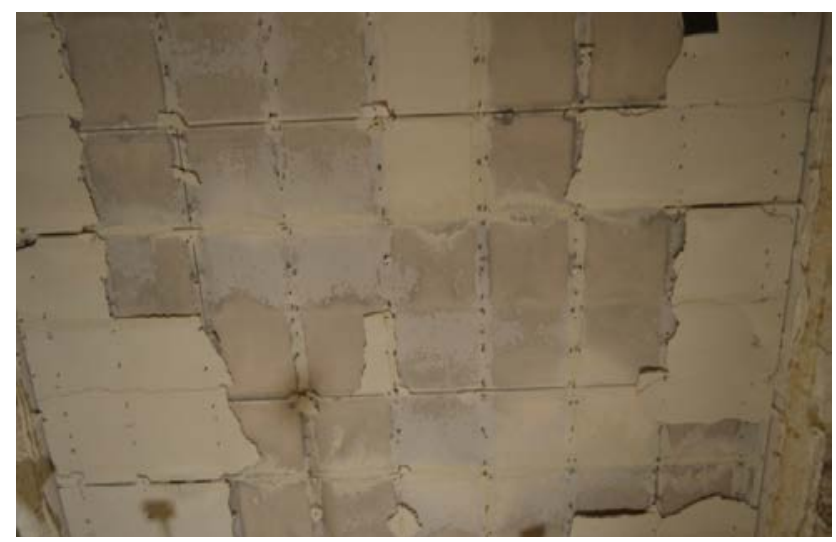

Photo 1. View of the suspended ceiling during the fire resistance test from the unexposed side

Fot. 1. Widok sufitu podwieszonego podczas badania odporności ogniowej od strony nienagrzewanej (źródto: archiwum ITB)

W normie klasyfikacyjnej PN-EN 13501-2 [6] podano kryteria klasyfikacyjne w zakresie odporności ogniowej w odniesieniu do wszystkich wymienionych w tej normie elementów budynku, w tym dla sufitów podwieszonych stanowiących samodzielne przegrody.

Kryteria oceny odporności ogniowej sufitów podwieszonych stanowiących samodzielne przegrody są następujące:

Szczelność ogniowa (E):

Oceny szczelności ogniowej należy dokonać na podstawie następujących trzech aspektów:

a) przekroczenia przez szczeliny lub otwory określonych wymiarów;

b) zapalenia tamponu z waty bawełnianej;

c) wystąpienia utrzymywania się płomienia na stronie nienagrzewanej.

Izolacyjność ogniowa (I):

Oceny izolacyjności ogniowej należy dokonać na podstawie następujących dwóch aspektów:

a) przekroczenia przyrostu średniej temperatury powierzchni nienagrzewanej o $140 \mathrm{~K}$ powyżej początkowej średniej temperatury;

b) przekroczenia przyrostu maksymalnej temperatury powierzchni nienagrzewanej o $180 \mathrm{~K}$ powyżej początkowej średniej temperatury.

$\mathrm{Na}$ fotografii 2 przedstawiono widok sufitu podwieszonego z okładzinami z płyt gipsowo-kartonowych po badaniu odporności ogniowej od strony nagrzewanej.

Photo 2. View of the suspended ceiling with gypsum plasterboard lining from the exposed side after the fire resistance test

Fot. 2. Widok sufitu podwieszonego po badaniu odporności ogniowej od strony nagrzewanej (źródto: archiwum ITB) 


\subsection{Fire resistance tests of systems: suspended ceiling-floor}

Fire resistance tests of systems: suspended ceilingfloor are carried out according to the standard PNEN 13381-1 [4]. The standard also refers to standards specifying the requirements of the test conditions and the criteria used: PN-EN 1363-1 [5] and PN-EN 13501-2 [6].

In the fire resistance test, a test specimen with the minimum dimensions of length $\left(\mathrm{L}_{\text {exp }}\right)$ of $4 \mathrm{~m}$ and width $\left(\mathrm{W}_{\text {exp }}\right)$ of $3 \mathrm{~m}$ shall also be subjected to the heat action defined by the standard time/temperature curve (1).

During the test, the test specimen is loaded with the load determined in accordance with EN 1363-1 [5]. The load magnitude is chosen so that it represents the actual imposed load. Normally, a uniformly distributed load is used.

The assessment consists in determining the influence of the horizontal protective membrane constituting the fire protection of the structural element, using the temperatures measured in the space between the suspended ceiling and the floor, under the heated surface of the structural element of the building. Fire resistance rating applies to the entire horizontal barrier - floor-suspended ceiling system.

\section{FIRE RESISTANCE CLASSIFICATION OF SUSPENDED CEILINGS}

The fire resistance classification of suspended ceilings is carried out in accordance with PN-EN 13501-2 [6]. In accordance with the principles of fire resistance testing of suspended ceilings described in paragraph 3 above, there are three possible cases of the test(s):

1) suspended ceiling constituting an independent barrier subjected to fire resistance test(s) in accordance with PN-EN 1364-2 [2] standard, under fire exposure from below;

2) suspended ceiling constituting an independent barrier subjected to fire resistance test(s) in accordance with PN-EN 1364-2 [2] standard, under fire exposure from above;

3) suspended ceiling not constituting an independent barrier, but applied as a protection of the floor (horizontal protective membrane), subjected to fire resistance test(s) in accordance with PN-EN 13381-1 [4] standard, as an element of the floorsuspended ceiling system (fire action as for the floor element - from below).

\subsection{Badania odporności ogniowej układów: strop-sufit podwieszony}

Badania odporności ogniowej układów: strop-sufit podwieszony wykonuje się według normy PN-EN 13381-1 [4]. Z uwagi na wymagania dotyczące warunków badań oraz stosowanych kryteriów norma ta odwołuje się także do norm: PN-EN 1363-1 [5] oraz PN-EN 13501-2 [6].

W badaniu odporności ogniowej element próbny o minimalnych wymiarach: długość $\left(\mathrm{L}_{\text {exp }}\right)-4 \mathrm{~m}$ i szerokość $\left(\mathrm{W}_{\mathrm{exp}}\right)-3 \mathrm{~m}$, poddawany jest także oddziaływaniu cieplnemu zdefiniowanemu standardową krzywą czas/temperatura (1).

Element próbny jest obciążony podczas badania obciążeniem wyznaczonym według PN-EN 1363-1 [5]. Wielkość obciążenia dobrana jest tak, aby reprezentowała rzeczywiste obciążenia użytkowe. Normalnie stosuje się obciążenie równomiernie rozłożone.

Ocena polega na ustaleniu wpływu poziomej membrany zabezpieczającej, stanowiącej zabezpieczenie ogniochronne elementu konstrukcyjnego, wykorzystując temperatury zmierzone $\mathrm{w}$ przestrzeni pomiędzy sufitem podwieszonym a stropem, pod nagrzewaną powierzchnią konstrukcyjnego elementu budynku. Ocena nośności ogniowej dotyczy całej przegrody poziomej - układu strop-sufit podwieszony.

\section{KLASYFIKACJA W ZAKRESIE ODPORNOŚCI OGNIOWE SUFITÓW PODWIESZONYCH}

Klasyfikacja w zakresie odporności ogniowej sufitów podwieszonych przeprowadzana jest zgodnie z normą PN-EN 13501-2 [6]. Zgodnie z opisanymi w punkcie 3 zasadami wykonywania badań odporności ogniowej sufitów podwieszonych możliwe są trzy przypadki wykonania badania(-ń):

1) sufit podwieszony stanowiący samodzielną przegrodę poddany badaniu(-om) odporności ogniowej według normy PN-EN 1364-2 [2], przy oddziaływaniu ognia od dołu;

2) sufit podwieszony stanowiący samodzielną przegrodę poddany badaniu(-om) odporności ogniowej według normy PN-EN 1364-2 [2], przy oddziaływaniu ognia od góry;

3) sufit podwieszony niestanowiący samodzielnej przegrody, lecz zastosowany jako zabezpieczenie stropu (pozioma membrana zabezpieczająca), poddany badaniu(-om) odporności ogniowej według normy PN-EN 13381-1 [4] jako element układu strop-sufit podwieszony (oddziaływanie ognia jak dla elementu stropowego - od dołu). 
In the first case, the classification is completed by the symbols $(\mathrm{a} \leftarrow \mathrm{b})$, which means that the classification remains valid for the suspended ceiling in question only when exposed to fire from below.

In the latter case, the classification is completed by the symbols $(a \rightarrow b)$, meaning that the classification remains valid for the suspended ceiling only when exposed to fire from above.

Where the fire resistance tests of suspended ceiling constituting an independent barrier have been carried under both exposures: fire from below and fire from above, the classification supplemented by symbols $(a \leftrightarrow b)$ is possible, i.e. what means that the classification remains valid for the suspended ceiling both when exposed to fire exposure from below and when exposed to fire exposure from above.

Symbols "a" and "b" are taken from the English words: "above" and "below".

In Table 1 possible fire resistance classifications of suspended ceilings constituting independent barriers are presented.
W pierwszym przypadku nadawana klasyfikacja jest uzupełniana symbolami ( $a \leftarrow b)$, co oznacza, że klasyfikacja pozostaje ważna dla danego sufitu podwieszonego tylko przy oddziaływaniu ognia od dołu.

W drugim przypadku nadawana klasyfikacja jest uzupełniana symbolami $(\mathrm{a} \rightarrow \mathrm{b})$, co oznacza, że klasyfikacja pozostaje ważna dla danego sufitu podwieszonego tylko przy oddziaływaniu ognia od góry.

W przypadku gdy badania odporności ogniowej sufitu podwieszonego, stanowiącego samodzielną przegrodę, zostały przeprowadzone zarówno przy oddziaływaniu ognia od dołu, jak i przy oddziaływaniu ognia od góry, możliwe jest nadanie klasyfikacji uzupełnionej symbolami ( $\mathrm{a} \leftrightarrow \mathrm{b})$, co oznacza, że klasyfikacja pozostaje ważna dla danego sufitu podwieszonego zarówno przy oddziaływaniu ognia od dołu, jak i przy oddziaływaniu ognia od góry.

Symbole ,a" i „b" przyjęto od angielskich określeń: powyżej - „above”, poniżej - „,below”.

W tabeli 1 zestawiono możliwe klasyfikacje sufitów podwieszonych stanowiących samodzielne przegrody w zakresie odporności ogniowej.

Table 1. Fire resistance classes of suspended ceilings constituting independent barriers according to EN 13501-2 [6]

Tabela 1. Klasy odporności ogniowej sufitów podwieszonych stanowiacych samodzielne przegrody wedtug normy $P N-E N$ 13501-2 [6]

\begin{tabular}{|c|c|c|}
\hline Fire exposure from above & Fire exposure from below & $\begin{array}{l}\text { Fire exposure from above and } \\
\text { fire exposure from below }\end{array}$ \\
\hline El $15(a \rightarrow b)$ & El $15(a \leftarrow b)$ & El $15(a \leftrightarrow b)$ \\
\hline El $30(a \rightarrow b)$ & El $30(a \longleftarrow b)$ & El $30(a \leftrightarrow b)$ \\
\hline El $45(a \rightarrow b)$ & El $45(a \leftarrow b)$ & El $45(a \leftrightarrow b)$ \\
\hline El $60(a \rightarrow b)$ & $\mathrm{El} 60(\mathrm{a} \longleftarrow b)$ & El $60(a \leftrightarrow b)$ \\
\hline El $90(a \rightarrow b)$ & El $90(a \leftarrow b)$ & El $90(a \leftrightarrow b)$ \\
\hline El $120(a \rightarrow b)$ & El $120(a \longleftarrow b)$ & El $120(a \leftrightarrow b)$ \\
\hline El $180(a \rightarrow b)$ & El $180(a \leftarrow b)$ & El $180(\mathrm{a} \leftrightarrow \mathrm{b})$ \\
\hline El $240(a \rightarrow b)$ & El $240(a \leftarrow b)$ & El $240(a \leftrightarrow b)$ \\
\hline
\end{tabular}

In all cases, in addition to determining the direction of fire exposure for which a classification is established, the scope of application of the classification should be determined, taking into account, for example, the permissible dimensions of the ceiling in relation to the size of the test specimen, the spacing of the structural elements, the method of fixing the ceiling, the height of the space between the suspended ceiling and the floor, the spacing and length of the hangers, the possibility of installing cables and pipes in the space above the suspended ceiling or the possibility of installing light accessories in the ceiling. PN-EN 1364-2 [2] specifies the range of changes that may be
We wszystkich przypadkach, poza określeniem kierunku oddziaływania ognia, dla którego klasyfikacja została ustalona, należy określić zakres zastosowania nadanej klasyfikacji, uwzględniając takie aspekty, jak np. dopuszczalne rozmiary sufitu w zależności od wielkości elementu badanego, rozstaw elementów konstrukcyjnych, sposób zamocowania sufitu, wysokość przestrzeni pomiędzy sufitem podwieszonym a stropem, rozstaw i długość wieszaków, możliwość umieszczenia $\mathrm{w}$ przestrzeni nad sufitem podwieszonym kabli i rur czy umieszczenie w suficie opraw oświetleniowych. W normie PN-EN 1364-2 [2] określono zakres zmian, które mogą być wprowadzone do 
introduced to the tested ceiling construction, which shall not change the fire resistance classification.

In the case of ceilings providing fire protection (protective membrane) of the floor, but not being independent barriers of a specified fire resistance, fire resistance, or precisely only loadbearing capacity of the floor-suspended ceiling system is determined as a result of fire resistance tests of the entire system and it depends on the limiting temperatures recorded in the space (cavity) between the tested floor and suspended ceiling, the limiting temperatures recorded on the surface of the structural elements of the tested floor and the type of the tested floor to which the ceiling is suspended. Limiting temperatures are the temperatures (defined for both cavity and surface) at which a floor made of a particular structural material will no longer be able to carry the load.

The adopted limiting temperatures determined for the temperature recorded in the cavity in the test specimen for each specified type of structural material, on the basis of which the loadbearing capacity is determined, are as follows:

$-600^{\circ} \mathrm{C}$ for all reinforced concrete building members;

$-530^{\circ} \mathrm{C}$ for building members containing steel beams plus reinforced concrete slabs;

$-450^{\circ} \mathrm{C}$ for reinforced concrete building members containing pre-stressed rebars/wires or strands;

$-400^{\circ} \mathrm{C}$ for building members containing steel/ concrete composites;

$-370^{\circ} \mathrm{C}$ for cold formed steel building members;

$-300^{\circ} \mathrm{C}$ for building members containing timber joists or structures with wooden floor boards.

The adopted limiting temperatures determined for the temperature recorded on the surface of the structural elements of the tested floor for each specified type of structural material, on the basis of which the loadbearing capacity is determined, are as follows:

$-510^{\circ} \mathrm{C}$ for building members containing steel beams plus reinforced normal or aerated concrete slabs (temperature measured on the steel beam);

$-350^{\circ} \mathrm{C}$ for cold formed steel building members (temperature measured on the steel element);

$-350^{\circ} \mathrm{C}$ for building members containing steel/ concrete composites (temperature measured on the profiled steel sheet of the composite slab).

Although for floors with horizontal protective membranes it is primarily expected that the loadbearing capacity $(\mathrm{R})$ criterion will be met, also the fire integrity (E) and fire insulation (I) criteria can be determined according to the procedures specified zbadanej konstrukcji sufitu, które nie zmienią nadanej klasyfikacji w zakresie odporności ogniowej.

W przypadku sufitów stanowiących zabezpieczenie ogniochronne (membranę zabezpieczającą) stropu, ale niestanowiących samodzielnych przegród o określonej odporności ogniowej, odporność ogniowa, a dokładnie tylko nośność ogniowa, układu strop-sufit podwieszony ustalana jest $\mathrm{w}$ wyniku badań odporności ogniowej całego układu i jest ona uzależniona od temperatur granicznych zarejestrowanych w przestrzeni (pustce) pomiędzy badanymi stropem a sufitem podwieszonym, temperatur granicznych zarejestrowanych na powierzchni elementów konstrukcyjnych stropu badanego oraz od rodzaju badanego stropu, do którego sufit jest podwieszony. Temperatury graniczne są temperaturami (zdefiniowanymi zarówno dla pustki, jak i dla powierzchni), w których strop zbudowany z określonego materiału konstrukcyjnego będzie niezdolny do dalszego przenoszenia obciążenia.

Przyjęte wartości temperatur granicznych ustalone dla temperatury rejestrowanej w pustce elementu badanego dla każdego określonego rodzaju materiału konstrukcji, na podstawie których określa się nośność ogniową, są następujące:

$-600^{\circ} \mathrm{C}$ dla wszystkich żelbetowych elementów budynku;

- $530^{\circ} \mathrm{C}$ dla elementów budynku zawierających belki stalowe plus płyty żelbetowe;

- $450^{\circ} \mathrm{C}$ dla wszystkich żelbetowych elementów budynku zawierających sprężone pręty/druty lub sploty;

$-400^{\circ} \mathrm{C}$ dla elementów budynku zawierających elementy zespolone stalowo-betonowe;

$-370^{\circ} \mathrm{C}$ dla zimnogiętych stalowych elementów budynku;

$-300^{\circ} \mathrm{C}$ dla elementów budynku zawierających drewniane żebra lub konstrukcje podłogowe $\mathrm{z}$ desek drewnianych.

Przyjęte wartości temperatur granicznych ustalone dla temperatury rejestrowanej na powierzchni elementów konstrukcyjnych stropu badanego dla każdego określonego rodzaju materiału konstrukcji, na podstawie których określa się nośność ogniową, są następujące:

- $510^{\circ} \mathrm{C}$ dla elementów budynku zawierających belki stalowe plus płyty żelbetowe $\mathrm{z}$ betonu zwykłego lub betonu komórkowego (temperatura mierzona na belce stalowej);

$-350^{\circ} \mathrm{C}$ dla zimnogiętych stalowych elementów budynku (temperatura mierzona na elemencie stalowym);

- $350^{\circ} \mathrm{C}$ dla elementów budynku zawierających elementy zespolone stalowo-betonowe (temperatury 
in the standard for the fire resistance testing of floors PN-EN 1365-2 [7].

\section{APPLICATION OF THE FIRE RESISTING SUSPENDED CEILINGS}

A suspended ceiling intended for the protection of the floor and its loadbearing structure can be designed as:

1. Part of the system: suspended ceiling - floor slab (or loadbearing structure of the floor slab), which together meets the requirements of the relevant fire resistance class with regard to load-bearing capacity (R), fire insulation (I) and fire integrity (E).

2. Independent barrier, which meets the criteria of fire integrity (E) and fire insulation (I).

In the first case it should be remembered that the fire resistance classification refers only to the exposure of fire from below (from the room side). This classification does not apply to the fire exposure from above. A fire in the space between the suspended ceiling (horizontal protective membrane) and the floor may occur if there are combustible materials in this space. As a result, the established assessment of the fire protection capability of the horizontal protective membrane may be invalidated by the presence of combustible materials in the space above the membrane. As it is difficult to determine the "representative" quantity of combustible materials that can be contained within this space, it is also difficult to determine the "representative" fire exposure.

Limitation of the possibility of presence of combustible materials and products in the space above the suspended ceiling/protective membrane is reflected in Polish building regulations. $\$ 232.1$ of the Regulation of the Minister of Infrastructure of 12 April 2002 on technical conditions to be met by buildings and their location [8] states that: "Walls and ceilings that are part of the fire separation elements shall be made of non-combustible materials ..." Therefore, when a horizontal barrier consisting of a floor and a suspended ceiling is used as a fire separating element, no combustible material will be allowed in the space between the suspended ceiling and the floor.

Taken into account that tests are generally performed without the presence of combustible materials in this space, the scope of application of the test and evaluation results generally does not cover the presence of combustible materials in the space between the membrane and the floor. The test configuration would need to take into account both mierzone na profilowanej blasze stalowej płyty zespolonej).

Chociaż w odniesieniu do stropów z poziomymi membranami zabezpieczającymi oczekuje się przede wszystkim spełnienia kryterium nośności ogniowej (R), również kryteria szczelności ogniowej (E) i izolacyjności ogniowej (I) mogą być ustalane zgodnie $\mathrm{z}$ procedurami określonymi w normie dotyczącej badań odporności ogniowej stropów PN-EN 1365-2 [7].

\section{STOSOWANIE SUFITÓW PODWIESZONYCH O OKREŚLONE ODPORNOŚCI OGNIOWEJ}

Sufit podwieszony, przeznaczony do ochrony stropu i jego konstrukcji nośnej, można projektować jako: 1. Część układu: sufit podwieszony-płyta stropowa (ewentualnie konstrukcja nośna płyty stropowej), który łącznie spełnia wymagania odpowiedniej klasy odporności ogniowej w zakresie nośności (R), izolacyjności ogniowej (I) i szczelności ogniowej (E).

2. Samodzielną przegrodę, która spełnia kryteria szczelności ogniowej (E) oraz izolacyjności ogniowej (I).

W pierwszym przypadku należy pamiętać, że nadana klasyfikacja w zakresie odporności ogniowej dotyczy tylko oddziaływania ognia od dołu przegrody (od strony pomieszczenia). Klasyfikacja ta nie dotyczy oddziaływania ognia od góry. Pożar w przestrzeni pomiędzy sufitem podwieszonym (poziomą membraną zabezpieczającą) a stropem może wystąpić, jeśli $\mathrm{w}$ tej przestrzeni będą znajdować się materiały palne. W efekcie ustalona ocena zdolności do zabezpieczania ogniochronnego poziomej membrany zabezpieczającej może zostać unieważniona na skutek obecności materiałów palnych w przestrzeni nad membraną. Ponieważ trudno określić „reprezentatywną" ilość materiałów palnych, które mogą znaleźć się w tej przestrzeni, trudno także określić „reprezentatywne" oddziaływanie ognia.

Ograniczenie możliwości występowania materiałów i wyrobów palnych w przestrzeni nad sufitem podwieszonym/membraną zabezpieczającą znajduje odzwierciedlenie w polskich przepisach techniczno-budowlanych. W § 232.1 Rozporządzenia Ministra Infrastruktury z dnia 12 kwietnia 2002 r. w sprawie warunków technicznych, jakim powinny odpowiadać budynki i ich usytuowanie [8], stwierdza się, że: „Ściany i stropy stanowiące elementy oddzielenia przeciwpożarowego powinny być wykonane z materiatów niepalnych, ...”. Zatem gdy przegroda pozioma złożona ze stropu i sufitu podwieszonego będzie pełnić funkcję oddzielenia przeciwpożarowego w przestrzeni 
the amount and the location of such materials and the final assessment would need to be limited to the test configuration. The maximum quantity of combustible materials that may be present in the space between the suspended ceiling (horizontal protective membrane) and the floor shall then be determined by national regulations.

In the latter case, if the suspended ceiling classification is specified for the fire exposure from below only or both from below and from above, the fire resistance of the floor is ensured, regardless of the fire resistance of the structure above the suspended ceiling; the installations are also protected against fire for the required period of time. The classification of a suspended ceiling as an independent barrier under fire exposure from above applies to the suspended ceiling only. It should be noted that more and more often the solutions of suspended ceilings for the fire exposure from below and for the fire exposure from above are differentiated, e.g. by using for the same structural solution an additional insulation layer laid on the ceiling for the fire exposure from above. As a result, two separate solutions are classified: one for the fire exposure from below (without insulation) and one for the fire exposure from above (with insulation).

In Polish building regulations [8], additional designations regarding fire resistance classes of suspended ceilings: $(a \leftarrow b), \quad(a \rightarrow b)$ and $(a \leftrightarrow b)$, specifying the direction of the fire exposure are not used. The fire performance requirements for floors and roofs (including suspended ceilings) apply only to the fire exposure from below. pomiędzy sufitem podwieszonym a stropem nie będą mogły znajdować się żadne materiały palne.

Biorąc pod uwagę, że badania wykonuje się na ogół bez obecności materiałów palnych w tej przestrzeni, zakres zastosowania wyników badania i oceny nie obejmuje na ogół występowania materiałów palnych w przestrzeni pomiędzy membraną a stropem. Konfiguracja badania musiałaby uwzględniać zarówno ilość, jak i umiejscowienie takich materiałów, a końcowa ocena musiałaby być ograniczona do konfiguracji badanej. Dopuszczalna ilość materiałów palnych, które mogą znajdować się w przestrzeni pomiędzy sufitem podwieszonym (poziomą membraną zabezpieczającą) a stropem, powinna być wówczas określona w przepisach krajowych.

W drugim przypadku, jeśli klasyfikacja sufitu podwieszonego została określona dla oddziaływania ognia tylko od dołu lub od dołu i od góry, zapewniona jest odporność ogniowa stropu, niezależnie od tego, jaka jest odporność ogniowa konstrukcji znajdującej się powyżej sufitu podwieszonego; także instalacje są chronione przed pożarem przez wymagany czas. Klasyfikacja sufitu podwieszonego jako samodzielnej przegrody przy oddziaływaniu ognia od góry, dotyczy wyłącznie sufitu podwieszonego. Należy zwrócić uwagę, że coraz częściej rozwiązania sufitów podwieszonych dla oddziaływania ognia od dołu i dla oddziaływania ognia od góry są różnicowane, np. przy tym samym rozwiązaniu konstrukcyjnym poprzez zastosowanie dodatkowej warstwy izolacyjnej ułożonej na suficie dla oddziaływania ognia od góry. W rezultacie klasyfikowane są odrębne dwa rozwiązania: jedno dla oddziaływania ognia od dołu (bez izolacji) i drugie dla oddziaływania ognia od góry (z izolacją).

W polskich przepisach techniczno-budowlanych [8] dodatkowe oznaczenia dotyczące klas odporności ogniowej sufitów podwieszonych: $(\mathrm{a} \leftarrow \mathrm{b}),(\mathrm{a} \rightarrow \mathrm{b})$ i $(a \leftrightarrow b)$, precyzujących kierunek oddziaływania ognia, nie są wykorzystywane. Wymagania w zakresie odporności ogniowej w odniesieniu do stropów i dachów (łącznie z sufitami podwieszonymi) odnoszą się wyłącznie do oddziaływania od dołu.

\section{References}

[1] PN-B-02875:1998 Ochrona przeciwpożarowa budynków - Metoda badania odporności ogniowej i skuteczności ogniochronnej sufitów podwieszonych. Fire protection of buildings - Method of testing for fire resistance and fire protection effectiveness of suspended ceilings.

[2] PN-EN 1364-2:2001 Badania odporności ogniowej elementów nienośnych - Część 2: Sufity EN 1364-2:1999 Fire resistance tests for non-loadbearing elements - Part 2: Ceilings.

[3] PN-EN 1364-2:2018-02 Badania odporności ogniowej elementów nienośnych-Część 2: Sufity EN 1364-2:2018 Fire resistance tests for non-loadbearing elements - Part 2: Ceilings. 
[4] PN-EN 13381-1:2014-12 Metody badań w celu ustalania wplywu zabezpieczeń na odporność ogniowa elementów konstrukcyjnych - Czesść 1: Poziome membrany zabezpieczajace EN 13381-1:2014. Test methods for determining the contribution to the fire resistance of structural members - Part 1: Horizontal protective membranes.

[5] PN-EN 1363-1:2012 Badania odporności ogniowej-Część 1: Wymagania ogólne. EN 1363-1:2012 Fire resistance tests - Part 1: General Requirements.

[6] PN-EN 13501-2:2016-07 Klasyfikacja ogniowa wyrobów budowlanych i elementów budynków-Część 2: Klasyfikacja na podstawie wyników badań odporności ogniowej, z wytączeniem instalacji wentylacyjnej EN 13501-2:2016. Fire classification of construction products and building elements - Part 2: Classification using data from fire resistance tests, excluding ventilation services.

[7] PN-EN 1365-2:2014-12 Badania odporności ogniowej elementów nośnych-Część 2:Stropy i dachy EN 1365-2:2014. Fire resistance tests for loadbearing elements - Part 2: Floors and roofs.

[8] Rozporządzenie Ministra Infrastruktury z dnia 12 kwietnia 2002 r. w sprawie warunków technicznych, jakim powinny odpowiadać budynki i ich usytuowanie. Dz.U. Nr 75 poz. 690, z późniejszymi zmianami. Regulation of the Minister of Infrastructure of 12 April 2002 on the technical conditions to be met by buildings and their location.

\section{Acknowledgments:}

The work was financed by Building Research Institute

\section{Podziekowania:}

Praca była finansowana przez Instytut Techniki Budowlanej 